\title{
THE ANTIBACTERIAL AND ANTIFUNGAL ACTION OF COPPER NANOPARTICLES IN VITRO IN RELATION TO PATHOGENIC TEST STRAINS AND CLINICAL ISOLATES OF MICROORGANISMS - CAUSATIVE AGENTS OF INFECTIOUS AND INFLAMMATORY PROCESSES OF DIFFERENT LOCALIZATION
}

\author{
A.V.Rudenko, P.V.Simonov, L.S.Rieznichenko, T.G.Gruzina, Z.R.Ulberg, I.S.Chekman \\ Institute of Urology at the NAMS of Ukraine \\ Bogomolets National Medical University \\ F.D.Ovcharenko Institute of Biocolloidal Chemistry at the NAS of Ukraine
}

Key words: copper nanoparticles; test strains; clinical isolates; antibacterial; antifungal action

\begin{abstract}
The results of determination of the antibacterial and antifungal action of $20 \mathrm{~nm}$ copper nanoparticles obtained according to the original protocol by the method of chemical condensation in the aqueous solution in relation to the broad spectrum of pathogenic test strains such as Staphylococcus aureus MRSA ATCC 43300, Escherichia coli ATCC 2592, Pseudomonas aeruginosa ATCC 27853, S. aureus 209P, Salmonella typhimurium 144, Shigella sonnei and Candida albicans, in testing sensitivity by the method of serial dilution in agar with the doses of microorganisms of 103-105 CFU/cm3 are presented in the article. Copper nanoparticles have shown the antibacterial and antifungal action on clinical isolates of causative agents of infectious and inflammatory processes of different localization isolated from surgical patients, such as S. aureus, E. coli, Proteus mirabilis, Klebsiella pneumoniae, Enterobacter aerogenes, P. aeruginosa, C. albicans, Candida non-albicans, Penicillium spp., Paecilomyces lilacinus, Aspergillus niger, and Aspergillus flavus, in testing sensitivity by the method of dosed drops with the dose for each microorganism of $107 \mathrm{CFU} / \mathrm{cm}^{3}$.
\end{abstract}

The study of pharmacological and toxicological properties of metal nanoparticles is of great interest nowadays since these nanostructures have unique characteristics and may be introduced into medicine as new medications. In recent years this problem is being studied in the framework of the joint research of the Pharmacology Department of the Bogomolets National Medical University, the F.D.Ovcharenko Institute of Biocolloidal Chemistry at the NAS of Ukraine, and the Institute of Urology at the NAMS of Ukraine [9, 10, 15].

Particularly, the efficacy of silver nanoparticles in the treatment of generalized infections in animals was determined [4]. A profound anti-anemic action of zerovalent iron nanoparticles was observed in the iron deficiency anemia model in rats [17]. Several studies on biosafety of silver and iron nanoparticles in vitro and in vivo were also carried out $[2,5,6]$.

It is reasonable to continue the research of pharmacological and toxicological properties of metal nanoparticles, in particular determination of the antimicrobial action of copper nanoparticles (CuNPs).
It is known that antibiotic resistance is an international healthcare problem and the cause of developing severe infections and complications, prolonged hospital stay, and increase in mortality [14]. A rapid increase in the number of strains simultaneously resistant to the third generation cephalosporins, fluoroquinolones, and aminoglycosides was noted in 2011 in one third of the European countries [20]. Despite of the increase in antibiotic resistance the rate of creation of new antimicrobial drugs decreases [21].

One of the possible ways to solve this problem is the intensification of development and introduction of a radically new class of antimicrobial drugs into medical practice with much less resistant strains compared to conventional antibiotics. Metal nanoparticles, especially CuNPs, are promising candidates for development of such medications [10,23].

It is well known that zero-valent copper and copper oxides show the antimicrobial action on viruses, fungi, and gram-positive and gram-negative bacteria $[13,19]$. As for CuNPs, a combination of their unique biological, 
physicochemical, and pharmacological properties with the antibacterial, antifungal, and antiviral action of metal determines the importance of their assessment as antimicrobial drugs of a new class.

Today the intensification of research of biocidal properties of CuNPs is observed. It has been determined that $\mathrm{CuO}$ nanoparticles with the size of $23 \mathrm{~nm}$ obtained by reduction of copper acetate with sodium hydroxide show the antimicrobial action in relation to Staphylococcus aureus, Enterococcus faecalis, Escherichia coli, Proteus vulgaris, Klebsiella pneumoniae, Salmonella typhimurium, Pseudomonas aeruginosa, and Shigella flexneri [11].

There are also publications describing the antimicrobial action of zero-valent CuNPs. For example, G.Ren et al. (2009) showed that zero-valent copper with the size of 22.4-94.8 $\mathrm{nm}$ obtained by the thermal plasma technology had the bactericidal action on S. aureus strains (including methicillin-resistant ones), Staphylococcus epidermidis, E. coli, Proteus spp., and P. aeruginosa [23]. It is known that CuNPs are also capable to inhibit the growth of fungi, such as Candida albicans, Alternaria alternata, Aspergillus flavus, Aspergillus niger, Fusarium solani, and Penicillium chrysogenum $[18,22]$.

The studies mentioned above were carried out on bacterial and fungal test strains and did not contain any data about the effect of CuNPs on clinical isolates of microorganisms. Scientific research of the latter is of great importance since such pathogens often exhibit the antimicrobial resistance to conventional antibiotics.

There is also the lack of data concerning biological safety of CuNPs in the studies mentioned above. It is important to provide an adequate risk/benefit ratio when developing new nanoparticle-based medicines.

The authors consider it appropriate to determine the antibacterial and antifungal action of zero-valent CuNPs obtained according to the original protocol by the method of chemical condensation in the aqueous solution since this substance is biosafe based on the results of cytotoxicity, genotoxicity and mutagenicity tests, as well as tests for biochemical biosafety markers in vitro [8] and acute toxicity when introducing it intravenously and intragastrically to white laboratory BALB/c line mice (LD50 va-lues are $443.7 \pm 56.5 \mathrm{mg} / \mathrm{kg}$ and $1839.1 \pm 210.2 \mathrm{mg} / \mathrm{kg}$, respectively). It is reasonable to carry out research on clinical isolates of microorganisms - causative agents of infectious and inflammatory processes of different localization isolated from surgical patients since they often exhibit the antibiotic resistance.

The aim of the study is to determine the antibacterial and antifungal action of CuNPs in vitro on pathogenic test strains and clinical isolates of microorganisms - causative agents of infectious and inflammatory processes of different localization.

\section{Materials and Methods}

The stable spherical zero-valent CuNPs with the size of $20 \mathrm{~nm}$ were obtained in F.D.Ovcharenko Institute of Biocolloidal Chemistry at the NAS of Ukraine (Kyiv) according to the original protocol by the method of chemical condensation in the aqueous solution. The substance was accompanied by the nanomaterial safety data sheet. According to it CuNPs do not show genotoxic, mutagenic, and cytotoxic properties in vitro and are biologically safe by biochemical markers, such as ATP-ase and LDH-ase activity [8].

The initial concentration of the nanoparticle substance comprised $32.0 \mathrm{mg} / \mathrm{ml}$ calculated with reference to metal.

The assessment of the antimicrobial action of CuNPs was carried out in vitro using two individual methods.

The antimicrobial action of the CuNP substance in relation to pathogenic test strains of microorganisms was determined by the method of serial dilution in agar according to the guidelines "Determination of microorganism sensitivity to antibacterial medicines" approved by the Order of the Ministry of Public Health of Ukraine N. 167 dated 05.04.2007 [3]. The test was performed on such strains as S. aureus MRSA ATCC 43300, E. coli ATCC 2592, P. aeruginosa ATCC 27853, S. aureus 209P, S. typhimurium 144, Shigella sonnei, and C. albicans from the collection of the State Scientific Control Institute of Biotechnology and Strains of Microorganisms (Kyiv).

The doses of test strains on Petri dishes were 103, 104 , and $105 \mathrm{CFU} / \mathrm{cm}^{3}$. The antibacterial and antifungal action of CuNPs was determined for the concentration of $6.4 \mathrm{mg} / \mathrm{ml}$ of CuNPs in the test medium (MullerHinton broth) calculated with reference to metal. Sterile CuNP medicines were added to sterile Muller-Hinton broth cooled to $50^{\circ} \mathrm{C}$, mixed and poured into Petri dishes. Microorganisms were incubated at $37^{\circ} \mathrm{C}$ for $24 \mathrm{~h}$.

The antibacterial and antifungal properties of $\mathrm{CuNPs}$ were also studied on clinical isolates of microorganisms - causative agents of infectious and inflammatory processes isolated from wounds, urine, and other biological material from surgical patients, such as bacteria of S. aureus, E. coli, Proteus mirabilis, K. pneumoniae, Enterobacter aerogenes, P. aeruginosa, fungi of Candida genus - C. albicans, Candida non-albicans, and other micromycetes - Penicillium spp., Paecilomyces lilacinus, A. niger, and A. flavus.

This phase of the study was carried out on the solid medium by the method of dosed drops. Microorganisms were inoculated as bacterial or fungal lawns on Petri dishes with the test medium (Mueller-Hinton agar for bacteria and Sabouraud agar for fungi) in the dose of $107 \mathrm{CFU} / \mathrm{cm}^{3}$. Microorganism suspensions were prepared on $0.9 \% \mathrm{NaCl}$ solution. After drying of plates with microorganism cultures for $30 \mathrm{~min}$ a drop of the CuNP solution with the initial concentration $(32.0 \mathrm{mg} / \mathrm{ml}$ calculated with reference to metal) or diluted ten-fold $(3.2 \mathrm{mg} / \mathrm{ml}$ calculated with reference to metal) was placed on the surface of each plate.

The CuNP concentration calculated with reference to metal in each drop $(\mathrm{V}=12.5 \mu \mathrm{l})$ was $0.40 \mathrm{mg}$ and $0.04 \mathrm{mg}$, respectively. Bacteria were incubated at $37^{\circ} \mathrm{C}$ for $24 \mathrm{~h}$, fungi of Candida genus - at $37^{\circ} \mathrm{C}$ for $48 \mathrm{~h}$, other micromycetes - at $28^{\circ} \mathrm{C}$ for 5 days. The results were assessed by measuring the zones of the complete growth inhibition.

All tests were carried out in triplicate. 
The antibacterial and antifungal action of copper nanoparticles on pathogenic test strains of microorganisms

\begin{tabular}{|c|c|c|c|}
\hline Test strain & $\begin{array}{c}\text { Dose of } \\
\text { the test } \\
\text { strain } \\
\left(\mathrm{CFU} / \mathrm{cm}^{3}\right)\end{array}$ & $\begin{array}{c}\text { Growth of } \\
\text { the test } \\
\text { strain in the } \\
\text { presence } \\
\text { of CuNP }\end{array}$ & $\begin{array}{l}\text { Control } \\
\text { growth } \\
\text { of the test } \\
\text { strain }\end{array}$ \\
\hline \multirow{3}{*}{$\begin{array}{l}\text { S. aureus } \\
\text { MRSA ATCC } \\
43300\end{array}$} & 103 & absent & ++++ \\
\hline & 104 & absent & ++++ \\
\hline & 105 & absent & ++++ \\
\hline \multirow{3}{*}{ E. coli ATCC 2592} & 103 & absent & ++++ \\
\hline & 104 & absent & ++++ \\
\hline & 105 & absent & ++++ \\
\hline \multirow{3}{*}{$\begin{array}{l}\text { P. aeruginosa } \\
\text { ATCC } 27853\end{array}$} & 103 & absent & ++++ \\
\hline & 104 & absent & ++++ \\
\hline & 105 & absent & ++++ \\
\hline \multirow{3}{*}{ S. aureus 209P } & 103 & absent & ++++ \\
\hline & 104 & absent & +++++ \\
\hline & 105 & absent & ++++ \\
\hline \multirow{3}{*}{$\begin{array}{l}\text { S. typhimurium } \\
144\end{array}$} & 103 & absent & ++++ \\
\hline & 104 & absent & ++++ \\
\hline & 105 & absent & ++++ \\
\hline \multirow{3}{*}{ S. sonnei } & 103 & absent & ++++ \\
\hline & 104 & absent & ++++ \\
\hline & 105 & absent & ++++ \\
\hline \multirow{3}{*}{ C. albicans } & 103 & absent & ++++ \\
\hline & 104 & absent & ++++ \\
\hline & 105 & absent & ++++ \\
\hline
\end{tabular}

Note: CFU - colony-forming unit, CuNPs - copper nanoparticles, ++++- an intensive growth of a microorganism; the concentration of CuNPs in the test medium $-6.4 \mathrm{mg} / \mathrm{ml}$ in metal equivalent.

\section{Results and Discussion}

While studying the antimicrobial properties of nanomaterials the right choice of the method for testing sensitivity, which would give relevant and reliable results, is important. It is known that the disc diffusion method is not optimal for nanoparticles because they may diffuse poorly in the solid media. This phenomenon is explained by the "molecular sieve" principle, the presence of charged polysaccharides and multiple sulphate and carboxyl groups in agar, which may readily interact with nanoparticles and impair their diffusion [7, 12, 24, 25]. Therefore, the use of this method may lead to obtaining of underestimated values of activity.

That is why the most adequate assessment of the antibacterial and antifungal action of nanoparticles can be obtained only with assurance of homogeneous distribution of nanoparticles in the test medium in contact with pathogen strains $[7,24]$. This may be achieved

using the method of serial dilution in agar or by application of a drop of the nanoparticle solution on the surface of the solid medium with further testing of the antimicrobial action on the area under the drop.

The antibacterial and antifungal action of copper nanoparticles on clinical isolates of microorganisms causative agents of infectious and inflammatory processes of different localization expressed in the inhibition zone diameters

\begin{tabular}{|c|c|c|c|}
\hline \multirow[b]{2}{*}{$\begin{array}{c}\text { Clinical isolates of } \\
\text { microorganisms }\end{array}$} & \multicolumn{3}{|c|}{ Inhibition zone diameter (mm) } \\
\hline & $\begin{array}{l}0.04 \mathrm{mg} \\
\text { CuNPs in a } \\
\text { drop }\end{array}$ & $\begin{array}{l}0.40 \mathrm{mg} \\
\text { CuNPs in a } \\
\text { drop }\end{array}$ & $\begin{array}{c}\text { Control } \\
\text { growth } \\
\text { (without } \\
\text { CuNPs) }\end{array}$ \\
\hline S. aureus & 6 & 11 & 0 \\
\hline E. coli & 7 & 11 & 0 \\
\hline P. mirabilis & 7 & 11 & 0 \\
\hline K. pneumoniae & 7 & 11 & 0 \\
\hline E. aerogenes & 7 & 11 & 0 \\
\hline P. aeruginosa & 6 & 11 & 0 \\
\hline C. albicans & 6 & 8 & 0 \\
\hline C. non-albicans & 5 & 12 & 0 \\
\hline Penicillium spp. & 5 & 8 & 0 \\
\hline P. lilacinus & 6 & 8 & 0 \\
\hline A. niger & 5 & 10 & 0 \\
\hline A. flavus & 6 & 8 & 0 \\
\hline
\end{tabular}

Note: CuNPs - copper nanoparticles; the dose of each microorganism was $107 \mathrm{CFU} / \mathrm{cm} 3$; the concentration of CuNPs is stated in metal equivalent.

The results of analysis of the antibacterial and antifungal action of CuNP in vitro on pathogenic test strains S. aureus MRSA ATCC 43300, E. coli ATCC 2592, P. aeruginosa ATCC 27853, S. aureus 209P, S. typhimurium 144, S. sonnei, and C. albicans are presented in Table 1.

It has been determined that CuNPs possessed a marked antibacterial and antifungal action on all pathogenic test cultures studied, the complete growth inhibition was observed with the doses of microorganisms on plates from $103 \mathrm{CFU} / \mathrm{cm}^{3}$ to $105 \mathrm{CFU} / \mathrm{cm}^{3}$.

The CuNPs studied also revealed the antibacterial and antifungal action on clinical isolates of microorganisms causative agents of infectious and inflammatory processes of different localization isolated from surgical patients, such as bacteria of S. aureus, E. coli, P. mirabilis, K. pneumoniae, E. aerogenes, P. aeruginosa, fungi of Candida genus C.albicans, C. non-albicans, and other micromycetes - Penicillium spp., P. lilacinus, A. niger, and A. flavus (Table 2). For cultures of S. aureus, E. coli, P. mirabilis, K. pneumoniae, E. aerogenes, P. aeruginosa, C. albicans, C. nonalbicans, Penicillium spp., P. lilacinus, A. niger, and A. flavus the complete growth inhibition was evident with the dose of each microorganism of $107 \mathrm{CFU} / \mathrm{cm}^{3}$ incubated with CuNPs in the concentration of $0.40 \mathrm{mg}$ and $0.04 \mathrm{mg}$ calculated with reference to metal in each drop. Thus, a marked antibacterial and antifungal action was determined for CuNP substance in the concentration of $32.0 \mathrm{mg} / \mathrm{ml}$ calculated with reference to metal and in ten-fold dilution $(3.2 \mathrm{mg} / \mathrm{ml}$ calculated with reference to metal). 
In this study the antibacterial and fungicidal action of CuNPs was determined not only in relation to the broad spectrum of pathogenic test strains, but also on clinical isolates of microorganisms - causative agents of infectious and inflammatory processes of different localization. It is known that microorganisms isolated from surgical patients are often antibiotic-resistant [20]. While analysing the literature data the authors did not find publications considering the antimicrobial properties of CuNPs on clinical isolates of microorganisms. The results of the current study motivate further scientific research in the field of development of new medicines with CuNPs obtained according to the original protocol by the method of chemical condensation in the aqueous solution.

Biosafety is an important feature of any medicine. The CuNPs applied in the current study were not genotoxic, mutagenic or cytotoxic in vitro [8] and were classified as the substance of the toxicity class 4 (low-toxic substances) according to the results of studying the acute toxicity after intravenous and intragastrical introduction in mice. It distinguishes these nanoparticles from other copper containing nanomaterials found in the literature $[1,16]$.

Therefore, the study conducted has shown that zerovalent CuNPs with the size of $20 \mathrm{~nm}$ obtained according to the original protocol by the method of chemical condensation in the aqueous solution possess the broad spectrum of the antibacterial and antifungal action. The authors consider it appropriate to continue studies of this substance as a potential antibacterial and antifungal medicine.

\section{CONCLUSIONS}

The spherical zero-valent copper nanoparticles with the size of $20 \mathrm{~nm}$ obtained according to the original protocol by the method of chemical condensation in the aqueous solution in relation to the broad spectrum of pathogenic test strains show a marked antibacterial and antifungal action on the broad spectrum of pathogenic test strains, namely S. aureus MRSA ATCC 43300, E. coli ATCC 2592, P. aeruginosa ATCC 27853, S. aureus 209P, S. typhimurium 144, S. sonnei, and C. albicans, in testing sensitivity by the method of serial dilution in agar with the doses of microorganisms of $103-105 \mathrm{CFU} / \mathrm{cm}^{3}$.

Copper nanoparticles have shown the antibacterial and antifungal action on clinical isolates of bacteria causative agents of infectious and inflammatory processes of different localization isolated from surgical patients, such as S. aureus, E. coli, P. mirabilis, K. pneumoniae, E. aerogenes and $\mathrm{P}$. aeruginosa, in testing sensitivity by the method of dosed drops with the dose for each microorganism of $107 \mathrm{CFU} / \mathrm{cm}^{3}$.

A marked antifungal action of copper nanoparticles on clinical isolates of such yeast fungi as C. albicans, C. non-albicans and other micromycetes - Penicillium spp., P. lilacinus, A. niger, and A. flavus isolated from surgical patients has been determined in testing sensitivity by the method of dosed drops with the dose for each microorganism of $107 \mathrm{CFU} / \mathrm{cm}^{3}$.

\section{REFERENCES}

1. Богословская О.А., Сизова Е.А., Полякова В.С. и др. // Вестник Оренбургского гос. университета. 2009. - №2. - C. 124-127.

2. Грузіна Т.Г., Дибкова С.М., Прискока А.О. та ін. // Фармакол. та лікарська токсикол. - 2012. - №3 (28). - C. 40-46.

3. Наказ МОЗ Украӥни від 05.04.2007 №167 «Про затвердження методичних вказівок «Визначення чутливості мікроорганізмів до антибактеріальних препаратів» [Електронний ресурс]. - Режим docmyny: http://mozdocs.kiev.ua/view.php?id=6958.

4. Прискока А.О., Резниченко Л.С., Ульберг 3.Р. и др. // Рещеепт. - 2014. - №5 (97). - С. 51-59.

5. Рєзніченко Л.С., Дибкова С.М., Дорошенко А.М. та ін. // Вісник проблем біол. і мед. - 2014. - Т. 2, №3. - C. 319-323.

6. Рєзніченко Л.С., Дорошенко А.М., Дибкова С.М. та ін. // Галищький лікарський вісник. - 2014. - №3. C. 59-62.

7. Рєзніченко Л.С., Руденко А.В., Сімонов П.В. та ін. // Вісник фармачії. - 2012. - №3 (71). - С. 75-78.

8. Трахтенберг I.М., Ульберг 3.Р., Чекман I.С. та ін. Оиінка безпеки лікарських нанопрепаратів: Метод. рекоменд. - К.: МОЗ України, 2013. - 108 с.

9. Чекман I.С. Нанофармакологія. - К.: Задруга, 2011. - 424 c.

10. Чекман I.С., Ульберг 3.Р., Маланчук В.О. та ін. Нанонаука, нанобіологія, нанофармаиія. - К.: Поліграф плюс, 2012. $-328 \mathrm{c}$.

11. Ahamed M., Alhadlaq H.A., Majeed Khan M.A. et al. // J. Nanomaterials. - 2014. - Vol. 2014, №637858. - P. 1-4.

12. Allahverdiyev A.M., Kon K.V., Abamor E.S. et al. // Expert Rev. Anti. Infect. Ther - 2011. - Vol. 9, №11. P. 1035-1052.

13. Borkow G., Gabbay J. // Curr. Chem. Biol. - 2009. - Vol. 3. - P. 272-278.

14. Cassir N., Rolain J.M., Brouqui P. // Front Microbiol. - 2014. - Vol. 5. - P. 551.

15. Chekman I.S., Ulberg Z.R., Gorchakova N.O. et al. // Lik. Sprava. - 2011. - №1-2. - P. 3-21. 
16. Chen Z., Meng H., Xing G. et al. // Toxicol. Lett. - 2006. - Vol. 163, №2. - P. 109-120.

17. Doroshenko A.M., Rieznichenko L.S., Dybkova S.M. et al. // Materials of FOURTH Symposium (IV) on "Bioinspired and biointegrated materials as frontiers nanomaterials”. - Warsaw, 2014. [Електронний ресурс]. Режим достуny: http://www.emrs-strasbourg.com.

18. Ghasemian E., Naghoni A., Tabaraie B. et al. // J. Mycol. Med. - 2012. - Vol. 22, №4. - P. 322-328.

19. Grass G., Rensing C., Solioz M. // Appl. Environ. Microbiol. - 2011. - Vol. 77, №5. - P. 1541-1547.

20. Llor C., Bjerrum L. // Ther. Adv. Drug Saf. - 2014. - Vol. 5, №6. - P. 229-241.

21. Mehta K.C., Dargad R.R., Borade D.M. et al. // J. Clin. Diagn. Res. - 2014. - Vol. 8, №6. - P. ME05-ME08.

22. Ramyadevi J., Jeyasubramanian K., Marikani A. et al. // Mater. Lett. - 2012. - Vol. 71. - P. 114-116.

23. Ren G., Hu D., Cheng E.W.C. et al. // Int. J. Antimicrob. Agents. - 2009. - Vol. 33. - P. 587-590.

24. Ruparelia J.P., Chatterjee A.K., Duttagupta S.P. et al. // Acta Biomater. - 2008. - Vol. 4, №3. - P. 707-716.

25. Singhal S.K., Lal M., Lata et al. // Nanosci. Nanotechnol. - 2012. - Vol. 3, №4. - P. 1-10.

\begin{abstract}
АНТИБАКТЕРІАЛЬНА ТА ПРОТИГРИБКОВА АКТИВНІСТЬ НАНОЧАСТИНОК МІДІ IN VITRO ЩОДО ПАТОГЕННИХ ТЕСТ-ШТАМІВ ТА КЛІНІЧНИХ ІЗОЛЯТІВ МІКРООРГАНІЗМІВ ЗБУДНИКІВ ІНФЕКЦІЙНО-ЗАПАЛЬНИХ ПРОЦЕСІВ РІЗНОЇ ЛОКАЛІЗАЦІЇ

А.В.Руденко, П.В.Сімонов, Л.С.Рєзніченко, Т.Г.Грузіна, З.Р.Ульберг, І.С.Чекман

Ключові слова: наночастинки міді; тест-штами; клінічні ізоляти; антибактеріальна та протигрибкова активність

Представлені результати визначення антибактеріальної та протигрибкової активності наночастинок міді розміром 20 нм, синтезованих за оригінальним протоколом методом хімічної конденсації у водному розчині, щодо широкого спектру патогенних тест-штамів, a саме: Staphylococcus aureus MRSA ATCC 43300, Escherichia coli ATCC 2592, Pseudomonas aeruginosa ATCC 27853, S. aureus 209P, Salmonella typhimurium 144, Shigella sonnei ma Candida albicans при визначенні чутливості мікроорганізмів методом серійних розведень в агарі за кінцевих засівних доз від 103 до 105 КУО/см³. Досліджені наночастинки міді виявили антибактеріальну та протигрибкову активність також щодо клінічних ізолятів збудників інфекційно-запальних процесів різної локалізації, виділених від хворих хірургічного профрілю: S. aureus, E. coli, Proteus mirabilis, Klebsiella pneumoniae, Enterobacter aerogenes, P. aeruginosa, C. albicans, Candida non-albicans, Penicillium spp., Paecilomyces lilacinus, Aspergillus niger ma Aspergillus flavus при визначенні чутливості мікроорганізмів методом дозованих крапель за кінцевої засівної дози $107 \mathrm{KУO} / \mathrm{cm}^{3}$.
\end{abstract}

\title{
АНТИБАКТЕРИАЛЬНАЯ И ПРОТИВОГРИБКОВАЯ АКТИВНОСТЬ НАНОЧАСТИЦ МЕДИ IN VITRO В ОТНОШЕНИИ ПАТОГЕННЫХ ТЕСТ-ШТАММОВ И КЛИНИЧЕСКИХ ИЗОЛЯТОВ МИКРООРГАНИЗМОВ - ВОЗБУДИТЕЛЕЙ ИНФЕКЦИОННО-ВОСПАЛИТЕЛЬНЫХ ПРОЦЕССОВ РАЗЛИЧНОЙ ЛОКАЛИЗАЦИИ
}

А.В.Руденко, П.В.Симонов, Л.С.Резниченко, Т.Г.Грузина, З.Р.Ульберг, И.С.Чекман

Ключевые слова: наночастицы меди; тест-штаммы; клинические изоляты; антибактериальная и противогрибковая активность

Представлены результаты определения антибактериальной и противогрибковой активности наночастиц меди размером 20 нм, синтезированных по оригинальному протоколу методом химической конденсации в водном растворе, в отношении широкого спектра патогенных тест-штаммов, а именно: Staphylococcus aureus MRSA ATCC 43300, Escherichia coli ATCC 2592, Pseudomonas aeruginosa ATCC 27853, S. aureus 209P, Salmonella typhimurium 144, Shigella sonnei и Candida albicans при определении чувствительности микроорганизмов методом серийных разведений в агаре при конечных посевных дозах от 103 до 105 KOE/см³. Исследованные наночастицы меди проявили антибактериальную и противогрибковую активность также в отношении клинических изолятов возбудителей инфекционно-воспалительных процессов различной локализации, выделенных от больных хирургического профиля: S. aureus, E. coli, Proteus mirabilis, Klebsiella pneumoniae, Enterobacter aerogenes, P. aeruginosa, C. albicans, Candida non-albicans, Penicillium spp., Paecilomyces lilacinus, Aspergillus niger $u$ Aspergillus flavus при определении чувствительности микроорганизмов методом дозированных капель при конечной посевной дозе 107 KOE/cM ${ }^{3}$. 